Universidade Tecnológica Federal do Paraná - UTFPR Campus Ponta Grossa - Paraná - Brasil

ISSN: 1981-3686/ v. 08, n. 02: p. 1428-1438, 2014 D.O.I. $10.3895 / \mathrm{S} 1981-36862014000200011$
Revista Brasileira de Tecnologia

Agroindustrial

\title{
METABOLIC PARAMETERS OF RATS FED WITH PRATO CHEESE CONTAINING YERBA MATE EXTRACT (Ilex paraguariensis St. Hill) AND PROBIOTICS CULTURES
}

\section{PARÂMETROS METABÓLICOS DE RATOS ALIMENTADOS COM QUEIJO TIPO PRATO CONTENDO EXTRATO DE ERVA-MATE (Ilex paraguariensis St. Hill) E CULTURA PROBIÓTICA}

\begin{abstract}
This study evaluated the profile of liver, kidney and blood glucose of rats after ingestion of cheese containing yerba mate extract and probiotics cultures. The rats received 5 g/animal per day of prato cheese containing yerba mate extract $(0.1 \%$ and $0.2 \%)$ and probiotics cultures for 30 days. The control group received basal diet and water ad libitum. The hepatic profile was assessed by measuring the activity of transaminases (AST and ALT), whereas renal profile was assessed by measuring levels of uric acid. The analysis was composed by cardiovascular morphometric analysis of the structure of the coronary arteries, diameter and thickness of the myocardium and its blood vessels. Glucose levels were assessed by measuring serum glucose. There was a significant increase in serum glucose and uric acid in animals that received cheese with yerba mate extract. The other parameters showed no significant changes. Prato cheese containing yerba mate extract and probiotics cultures did not alter metabolism of rats.
\end{abstract}

Keywords: cheese; metabolism; probiotics; rats; yerba mate.

\section{Introduction}

Ilex paraguariensis St. Hill is used in folk medicine and is recommended by herbalists for arthritis, headache, constipation, rheumatism, hemorrhoids, obesity, fatigue, fluid retention, 
hypertension, slow digestion and liver disorders. Due to these properties, it is included in major pharmacopoeias as Martingdale and Bristish Herbal Pharmacopeia (Arçari et al, 2009).

Europe, United States, Japan and Syria import leaves of yerba mate and market them in the form of herbal extract, which is used in the formulation of phytotherapic products, used in treatments for obesity and also as a dietary supplement, because of its content of vitamins and minerals (Carducci et al, 2000), and also due to its energizing and invigorating action, because it contains methylxanthines, caffeine and theobromine (Filip et al, 2000).

When used as a drink, yerba mate (mate and mate tea) has antioxidant properties, hepatoprotective, vasodilator, gastrointestinal, and hypocholesterolemic action already proven in vivo and in vitro (Baisch et al, 1998; Filip et al, 2000; Gorzalczany et al, 2001; Gugliucci and Menini 2002; Arçari et al, 2009). Many of these properties, especially the antioxidant ones, are due to the presence of phenolic acids, which are present in high concentrations in beverages (Cliford and Ramirez-Martinez, 1990; Mazzafera, 1997; Carini et al, 1998; Filip et al, 2001; Bastos et al, 2005; Bastos et al, 2006), and the consumption of products containing yerba mate could contribute to the prevention of atherosclerosis and cancer (Miranda et al, 2008).

Antioxidants are substances capable of preventing the deleterious effects of oxidation, since they sequester free radicals. The antioxidants vitamin C, vitamin E, carotenoids and flavonoids have received more attention for their possible beneficial effect on blood glucose levels and prevention of atherosclerotic disease (Rodrigues et al, 2003). Research has shown that yerba mate has antioxidant activity equivalent or superior to vitamin C and vitamin E (Arçari et al, 2009).

Most cheeses produced worldwide are made with whole milk (Akoh, 1998; Kondyli et al, 2002). The prato cheese presents half-baked and washed mass, mild flavor and smooth consistency. According to Costa Júnior and Pinheiro (1998), it became the second most consumed type of cheese in Brazil, being used mostly in sandwiches or as a cooking ingredient.

Over the past 80 years, the prato cheese has undergone many modifications, either in manufacturing technology or in the way of how it is consumed. In the manufacturing of Brazilian prato cheese, modern equipment and different methods of manufacture and ripening are used, which promote the development of typical features of texture and flavor that are different from those of Danish cheese (Furtado and Amorim, 2000).

Functional foods are characterized by offering several health benefits, beyond the nutritional value inherent to their chemical composition, and they may play a potential beneficial role in reducing the risk of chronic degenerative diseases, since they can act on the gastrointestinal system and cardiovascular system, metabolism, growth, development and cell differentiation; on the behavior of physiological functions and also act as antioxidants (Souza et al, 2003). But their role in 
relation to diseases is, in most cases, more focused on risk reduction rather than prevention (Moraes and Colla, 2006).

There is enough information about the properties and the beneficial health effects of beverages containing yerba mate, but not on the atomized extract of yerba mate in a powdered form associated with the traditional prato cheese and prato cheese with mesophilic cultures. A study conducted by our group with yogurt containing extract of yerba mate and yoghurt containing extract of yerba mate and mesophilic cultures with probiotic activity found that total cholesterol levels tended to decrease in rats fed with yogurt containing only extract of yerba mate (Ril et al, 2011). This previous information guided the preparation of this research, whose aim was to evaluate the effect of prato cheese containing probiotic cultures, with and without extract of yerba mate, in different concentrations, on lipid profile, glucose, liver and kidney of rats fed with these two types of cheese.

\section{Material and methods}

\section{Yerba mate extract}

The leaves of yerba mate were roasted at $180^{\circ} \mathrm{C}$ for 5 minutes in pilot bench toaster (trade mark Intecnial). After the leaves were dried in a bench fixed bed reactor with circulating hot air at a temperature of $70^{\circ} \mathrm{C}$ until the moisture was below 5\%, and crushed in a grinder of knives (trade mark Walita) until they reached an average diameter of $3.88 \mathrm{~mm}$. We used $22 \mathrm{~g}$ of dried leaves crushed and submitted to the extractor (trade mark Bialetti) in fixed bed percolation of $350 \mathrm{~mL}$ of solvent (water) under heating. The yerba mate extract was dried by atomization in a spray dryer, (Lab Plant SD-05), as described by Valduga (2002).

\section{Prato cheese}

Three kinds of cheese were prepared:

- Cheese with mesophilic culture (Lactococcus lactis subsp lactis and Lactococcus lacis sbsp cremoris) without yerba mate extract;

- Cheese with mesophilic culture (Lactococcus lactis subsp and Lactococcus lactis sbsp cremoris) with $0.1 \%$ of yerba mate extract;

- Cheese with mesophilic culture (Lactococcus lactis subsp lactis and Lactococcus lactis sbsp cremoris with $0.2 \%$ of yerba mate extract. 
Fifty liters of milk pasteurized at $75^{\circ} \mathrm{C}$ for 15 seconds, with $3.2 \%$ fat, were placed in stainless steel tank, and after were added $20 \mathrm{~mL}$ of calcium chloride 40\% (Chr Hansen), $2 \mathrm{~mL}$ of dye annatto (Chr Hansen), $0.57 \mathrm{~g}$ of coagulant produced by fermentation from Aspergillus niger var. awamori (Chymax of the Chr Hansen), $6.25 \mathrm{U}$ of mesophilic culture (Lactococcus lactis subsp lactis and Lactococcus lactis sbsp cremoris, of the ISP).

Coagulation occurred at $35^{\circ} \mathrm{C}$, and cutting the curd was done 40 minutes after the addition of coagulant. The mass was heated at $45^{\circ} \mathrm{C}$ and remained at rest for 5 minutes. After the mass was deposited on the tank bottom, the withdrawal of serum and subsequent washing of the mass occurred. When the mass was ready it was weighted to calculate the amount of sodium chloride to be added (1.5\% on the weight of mass).

After salting the mass, the extract of yerba mate was added $(0.1$ and $0.2 \%)$ in the formulation two and three, then the mass was put in the forms $(250 \mathrm{~g})$, which were taken to the hydraulic press and subjected to the first pressing at $20 \mathrm{lbf} / \mathrm{pol}^{2}$ for 60 minutes. By the end of that time, the cheeses were inverted within the shapes and the forms exchanged places in the press and then the second pressing at $30 \mathrm{lbf} / \mathrm{pol}^{2}$ occurred for 120 minutes. At the end of the pressing, the cheeses were vacuum packed and taken to the ripening chamber, where they remained for 60 days at $15^{\circ} \mathrm{C}$ and $85 \%$ of relative humidity. After this period of maturation, the treatment of the animals was iniciated.

\section{Animals}

The sample was composed by 24 Wistar adult male rats, with an average initial weight of $220 \mathrm{~g}$, from the Laboratory of Animal Experiments of Regional Integrated University of Alto Uruguai and Missões - Campus Erechim. During the experimental period (30 days) the animals were kept at a temperature of $23^{\circ} \mathrm{C}( \pm 2)$, light-dark period of 12 hours and water ad libitum. The study was conducted according to ethical standards according to Brazilian Society of Science in Animals of Laboratory and research protocol was approved by the Ethics Committee of Regional Integrated University of Alto Uruguai and Missões - Campus Erechim under number 024/PIA/09.

\section{Animals treatment}

Twenty-four rats were divided into four groups $(n=6)$ : group 1 was the control group, which received a commercial feed (Nuvital $\left.{ }^{\circledR}\right)$; in groups 2, 3 and 4, each animal received $5 \mathrm{~g}$ cheese /day of different formulations for 30 days. Group 2 received cheese containing mesophilic culture; group 
3 received cheese containing $0.1 \%$ of extract of yerba mate and mesophilic culture and group 4 received cheese containing $0.2 \%$ extract of yerba mate and mesophilic culture.

The amount of $5 \mathrm{~g}$ of cheese per animal was determined based on a study of our research group with yogurt containing extract of yerba mate (Ril et al. 2011). During 30 days, the rats were evaluated for clinical signs of toxicity (piloerection, salivation, diarrhea, convulsions, tremor, loss of hair and behavior).

After 30 days, the animals received anesthesia with Zoletil $50 \circledR$ at a dose of $50 \mathrm{mg} / \mathrm{kg}$, intraperitoneally. Blood was collected from abdominal aorta to obtain serum, which was used for biochemical evaluation.

\section{Biochemical parameters}

The blood was centrifuged at $3500 \mathrm{rpm}$ in bench top centrifuge (trade mark Fanem®) for 10 minutes to obtain serum that was used for biochemical testing.

The lipid profile was assessed by determinations of total cholesterol, HDL cholesterol and triglycerides. The hepatic profile was evaluated by determining the activity of aspartate aminotransferase (AST) and alanine aminotransferase (ALT), while the evaluation of renal function was determined by seric levels of uric acid. Blood glucose was also determined by serum. For the determination of these biochemical parameters, BioTécnica® kits were used. The tests were performed in semi-automated device Bio plus 2000.

\section{Cardiovascular anatomical analysis}

The myocardium, pericardium and coronary arteries of the animals fed with the formulations or not (control group - normal market diet for rats) were analyzed macroscopically and microscopically. After 30 days of administration of the formulations, the animals were exsanguinated and organs collected, identified and morphometric data collected, such as diameter and length of cardiac muscle, general macroscopic aspect, thickness of each compartment of the myocardium and possible changes in tissues and cardiac vessels. After the dissection of these structures, the organs were fixed in $10 \%$ formalin. For microscopic analysis, fragments of each organ or sections were collected. They were fixed in $10 \%$ buffered formalin, stained with hematoxylin and eosin. After the processing, the sections were examined under light microscope and images taken at different objectives for documentation. The results of these techniques allow us to describe possible changes in the structure of these organs in relation to control group. 
The results were expressed as mean plus or minus standard deviation, which were statistically analyzed by analysis of variance (ANOVA) followed by Tukey test at 95\% ( $\mathrm{P}<0.05)$, with the aid of GraphPad Prism version 5.0.

\section{Results}

Table 1 shows the lipid profiles, glucose, liver and kidney of rats fed with the three formulations of cheese. Throughout the study period, no signs of toxicity or death were observed in all rats of the four groups. The lipid profile (total cholesterol, HDL cholesterol and triglycerides) was not changed in all groups, eating cheese with or without extract of yerba mate did not cause dyslipidemia, considering 30 days of ingestion ( $5 \mathrm{~g} /$ day). However, there was a significant increase of glucose levels in the groups receiving cheese with yerba mate extract $(0.1$ and $0.2 \%)$ compared to the control group and the group that received cheese without extract (group 2).

The parameters analyzed in relation to hepatic profile did not change in all groups. In the renal profile, uric acid levels increased significantly in animals that received cheese supplemented with 0.1 and $0.2 \%$ of mate when compared to animals that received cheese without extract and control group (Table 1).

Table 1 - Biochemical parameters of rats in different groups

\begin{tabular}{ccccc}
\hline Biochemical parameters & Group 1 & Group 2 & Group 3 & Group 4 \\
\hline Total cholesterol (mg/dL) & $40.33 \pm 10.17^{\mathrm{a}}$ & $33.67 \pm 10.41^{\mathrm{a}}$ & $43.83 \pm 8.42^{\mathrm{a}}$ & $38.17 \pm 10.80^{\mathrm{a}}$ \\
HDL cholesterol (mg/dL) & $21.00 \pm 8.83^{\mathrm{a}}$ & $27.83 \pm 19.54^{\mathrm{a}}$ & $41.75 \pm 20.76^{\mathrm{a}}$ & $27.17 \pm 12.66^{\mathrm{a}}$ \\
Triglycerides (mg/dL) & $74.20 \pm 27.87^{\mathrm{a}}$ & $59.83 \pm 22.19^{\mathrm{a}}$ & $76.17 \pm 26.62^{\mathrm{a}}$ & $63.83 \pm 26.06^{\mathrm{a}}$ \\
Glucose (mg/dL) & $82.67 \pm 11.98^{\mathrm{a}}$ & $89.33 \pm 11.41^{\mathrm{a}}$ & $121.00 \pm 34.79^{\mathrm{b}}$ & $129.00 \pm 22.10^{\mathrm{b}}$ \\
AST (U/L) & $86.60 \pm 21.65^{\mathrm{a}}$ & $96.50 \pm 27.44^{\mathrm{a}}$ & $74.50 \pm 9.95^{\mathrm{a}}$ & $96.50 \pm 19.15^{\mathrm{a}}$ \\
ALT (U/L) & $41.40 \pm 6.54^{\mathrm{a}}$ & $37.83 \pm 5.49^{\mathrm{a}}$ & $34.75 \pm 4.79^{\mathrm{a}}$ & $38.00 \pm 4.47^{\mathrm{a}}$ \\
Uric acid (mg/dL) & $0.63 \pm 0.08^{\mathrm{a}}$ & $0.53 \pm 0.25^{\mathrm{a}}$ & $1.08 \pm 0.37^{\mathrm{b}}$ & $1.02 \pm 0.40^{\mathrm{b}}$ \\
\hline
\end{tabular}

Group 1: control, Group 2: cheese with culture and without extract of yerba mate, Group 3: cheese with $0.1 \%$ extract of yerba mate and culture, Group 4: cheese with $0.2 \%$ extract yerba mate and culture. The letters in the same line are not statistically different.

Table 2 presents the morphometric data of the myocardium. Although the control group (group 1) show higher averages in some measurements, it is not possible to say that cheese with yerba mate extract (groups 3 and 4) have effectively contributed to this result, indicating that differences may represent a normal variation, an anatomical finding. In histological analysis of coronary arteries, a slight thickening of the vascular wall was observed in all groups, but no significant changes were observed between the control group and other representative groups that received the extract of yerba mate. 
Table 2 - Morphometric analysis of myocardium.

\begin{tabular}{ccccc}
\hline Parameters (mm) & Group 1 & Group 2 & Group 3 & Group 4 \\
\hline Total length & $15.50 \pm 0.70^{\mathrm{a}}$ & $15.88 \pm 0.74^{\mathrm{a}}$ & $15.03 \pm 1.85^{\mathrm{a}}$ & $15.56 \pm 0.74^{\mathrm{a}}$ \\
Laterolateral thickness & $12.71 \pm 0.91^{\mathrm{a}}$ & $12.04 \pm 0.62^{\mathrm{a}}$ & $11.30 \pm 1.34^{\mathrm{a}}$ & $10.59 \pm 0.22^{\mathrm{b}}$ \\
Dorsal-ventral thickness & $9.36 \pm 1.39^{\mathrm{a}}$ & $8.19 \pm 2.17^{\mathrm{a}}$ & $8.40 \pm 1.79^{\mathrm{a}}$ & $9.77 \pm 0.44^{\mathrm{a}}$ \\
Thickness of the right atrium & $0.77 \pm 0.09^{\mathrm{a}}$ & $0.70 \pm 0.08^{\mathrm{a}}$ & $0.70 \pm 0.08^{\mathrm{a}}$ & $0.72 \pm 0.12^{\mathrm{a}}$ \\
Thickness of the right ventricule & $1.74 \pm 0.54^{\mathrm{a}}$ & $1.17 \pm 0.09^{\mathrm{a}}$ & $1.05 \pm 0.06^{\mathrm{b}}$ & $1.14 \pm 0.10^{\mathrm{b}}$ \\
Thickness of the left atrium & $0.92 \pm 0.09^{\mathrm{a}}$ & $0.77 \pm 0.05^{\mathrm{a}}$ & $0.87 \pm 0.15^{\mathrm{a}}$ & $0.95 \pm 0.13^{\mathrm{a}}$ \\
Thickness of the left ventricule & $2.98 \pm 0.42^{\mathrm{a}}$ & $2.54 \pm 0.39^{\mathrm{a}}$ & $2.48 \pm 0.35^{\mathrm{a}}$ & $2.47 \pm 0.36^{\mathrm{a}}$ \\
\hline Group 1: control, Group 2: cheese with culture and without extract of yerba mate, Group 3: cheese with 0.1\% extract of yerba mate and culture, \\
Group 4: cheese with 0.2\% extract yerba mate and culture. The letters in the same line are not statistically different.
\end{tabular}

\section{Discussion}

Levels of total cholesterol, HDL and triglycerides there was no significant difference between groups $(\mathrm{P}>0.05)$. In all groups the results were similar and in agreement with the reference values for rats (Mitruka and Rawnsley, 1977).

According to the Brazilian Society of Cardiology (2001), lipid abnormalities are more frequent: hypertriglyceridemia, hypercholesterolemia, decreased concentrations of high density lipoprotein (HDL) and higher concentrations of low density lipoprotein (LDL), which may occur alone or combined. The change of serum lipid is cholesterol, its fractions and triglycerides is an important factor for the onset of cardiovascular disease (CVD) of atherosclerotic origin (Gianini, 1998).

The rates of HDL were higher in groups of animals that received cheese (groups 2, 3 and 4); no significant difference was observed in the control group, which can be interpreted as a tendency that the cultures and also the extract of mate associated with the cheese would increase the levels of HDL cholesterol, which is important because it is considered the good cholesterol that acts as a protection against cardiovascular diseases (Williams, 1996; Siervogel et al, 1998; Bemben and Bemben, 2000; Krauss, 2004).

Values of triglycerides and total cholesterol showed no significant difference between groups. The discussion on the contribution of triglycerides (TG) in atherogenesis is still under discussion and the serum is routinely justified by the frequent binding to atherosclerotic CVD and by association with other metabolic disorders (Gianini, 1998). Moreover, normalization of serum lipids is reducing total cholesterol, LDL and TG and raising HDL, significantly reduces the appearance of atherosclerotic CVD source (Manninen et al, 1988). 
The serum aminotransferases reports the degree of injury to hepatocytes, since its release in the serum can mean cell death. Serum ALT is the best indicator for assessing the integrity of the liver cell of the AST (Awadalla et al, 1975). Hepatic profile in both AST and ALT showed no significant differences in their activities, indicating then that there was no change in the liver of animals receiving cheese supplemented with extract of yerba mate.

Results showed an increase in glucose levels in groups 3 and 4 which are the groups that received the cheese with yerba mate extract in different concentrations. But if considering the values obtained with the reference values, which are 50 to $135 \mathrm{mg} / \mathrm{dL}$, we observed that these are within limits (Mitruka and Rawnsley, 1977). The increase of glucose levels in rats fed with milk products containing extracts of yerba mate was also observed in a previous study (Ril et al, 2011), but there was no significant difference between groups. Arçari (2009) also found no significant difference in glucose levels between mice receiving mate tea and mice not receiving mate tea after 120 days of study, even though those receiving $1 \mathrm{~g}$ of mate tea per $\mathrm{kg}$ showed a higher glucose level. These results differ from the present study, where increased blood glucose level was significant when animals were treated with extracts containing cheese mate of $0.1 \%$ and $0.2 \%$.

Kidneys perform a lot of functions that can be characterized as didactically filtration, reabsorption, homeostasis, endocrine and metabolic functions. In the evaluation of renal uric acid, the groups of animals that received cheese with yerba mate extract (groups 3 and 4) had higher values of uric acid when compared to groups that did not receive mate associated with cheese. Uric acid and its salts are the end products of purine metabolism. Elevated level of this element in blood indicates the presence of renal diseases that reduce the excretion of products, and show drug abuse and use of certain medications (Neweman and Price, 1999). This change will be investigated thorough a study of renal function in these animals, including the determination of urea, creatinine and histological analysis of kidneys.

All groups that received the formulations (groups 2, 3 and 4) showed thickening in some areas on the cardiovascular system, especially in the coronary arteries and myocardial walls, compared with normal histological parameters known, probably due to the lipid dietary which groups were submitted. In interpreting the results of measurements of the structures of the heart, anatomical morphometric analysis of myocardium showed equivalent measurements between groups, with little variation in the control group compared to other groups. In the control group, means were slightly higher than the averages shown in some measurements. A thickening of the vascular endothelium and consequently the development of atherosclerotic coronary disease is directly associated with abnormal lipid metabolism, but is also exacerbated by almost any factor that injures the arterial wall, particularly high blood cholesterol is often associated with changing thickness the endothelial wall (Guyton 1972). Although it not possible to say that supplementation 
with the extract of mate has contributed to these changes, we noticed a slight but noticeable difference in means between groups 1 and 2, which received the extract of mate, when compared with group 3, extract supplemented with $0.1 \%$ and group 4 , supplemented with $0.2 \%$ extract, especially in measurements related to laterolateral thickness of the myocardium and right ventricle.

\section{Conclusion}

The animals were fed with cheese supplemented with extract of yerba mate $(0.1 \%)$ tended to raise levels of HDL cholesterol, the good cholesterol, but at the same time significantly increased levels of glucose and uric acid. While the animals fed with cheese supplemented with $0.2 \%$ extract of yerba mate showed no tendency to raise HDL cholesterol levels but also produced significant increase in serum glucose and uric acid. These data direct future studies in rats with dyslipidemia and toxicity of extract of yerba mate.

\section{Resumo}

Este estudo avaliou o perfil hepático, renal e a glicemia de ratos submetidos à ingesta de queijo prato contendo extrato de erva-mate e culturas mesófilas. Os ratos receberam $5 \mathrm{~g}$ de queijo prato por animal/dia contendo extrato de erva-mate $(0,1 \%$ e 0,2\%) e também probióticos por 30 dias. $O$ grupo controle recebeu dieta basal e água ad libitum. O perfil hepático foi avaliado por medida da atividade das transaminases (AST e ALT), enquanto que o perfil renal foi avaliado pela dosagem de ácido úrico. A análise cardiovascular foi composta de análise morfométrica da estrutura das artérias coronárias, diâmetro e espessura do miocárdio e seus vasos sanguíneos. O nível glicemico foi avaliado pela dosagem de glicose sérica. Houve um aumento significativo dos níveis de glicose e ácido úrico nos animais que receberam queijo com extrato de erva-mate. Nos demais parâmetros analisados não houve alteração significativa.

Palavras-chave: queijo prato; metabolismo; probióticos; ratos; erva-mate.

\section{References}

AKOH C. C. Fat replacers. Food Technology. v.52, p. 47-53, 1998.

ARÇARI, D. P.; BARTCHEWSKY, W.; DOS SANTOS, T. W.; OLIVEIRA, K. A.; FUNK, A.; PEDRAZZOLI, J.; DE SOUZA, M. F.; SAAD, M .J.; BASTOS, D. H.; GAMBERO, A.; CARVALHO, P. O.; RIBEIRO. Antiobesity effects of yerba mate extract (Ilex paraguariensis) in high-fat diet-induced obese mice. Obesity. v. 17, p. 2127-2133, 2009. http://dx.doi.org/10.1038/oby.2009.158.

AWADALLA, H.N.; SHERIF, A.F.; SHAFEI, A.Z.; KHALIL, H.A.; GUIRGIS, F.K. Enzyme levels in homogenates of liver from mice infected with schistosoma mansoni and from uninfected mice. International Journal for Parasitology. v.5, p.27-31, 1975. http://dx.doi.org/10.1016/0020-7519(75)90093-4. 
BAISCH, A. I. M.; JOHNSTON, F. L.; STEIN, P. Endothelium-dependent vasorelaxing activity of aqueous extracts of Ilex paraguariensis on mesenteric arterial bed of rats. Journal of Ethnopharmacology. v.60, p.133-139, 1998. http://dx.doi.org/10.1016/S0378-8741(97)00140-2

BASTOS, D. H. M.; FORNARI, A. C.; QUEIROZ, Y. S.; MANOLIO, R. S.; TORRES, E. A. F. S. The chlorogenic acid and caffeine content of yerba mate (Ilex paraguariensis) beverages. Acta Farmaceutica Bonaerense. v.24, p.9195, 2005.

BASTOS, D. H. M.; FORNARI, A. C.; QUEIROZ, Y. S.; TORRES, E. A. F. S. Bioactive compounds content of chimarrão infusions related to the moisture of yerba mate (Ilex paraguariensis) leaves. Brazilian Archives of Biology and Technology. v.49, p.399-404, 2006. http://dx.doi.org/10.1590/S1516-89132006000400007

BEMBEN, D. A.; BEMBEN, M. G. Effects of resistance exercise and body mass index on lipoprotein-lipid patterns of postmenopausal women. The Journal of Strength and Conditioning Research. v.14, p.80-85, 2000.

CARDUCCI, C. N.; DABAS, P. C.; MUSE, J. O. Determination of inorganic cations by capillary ion electrophoresis in Ilex paraguariensis (St. Hill), a plant used to prepare tea in South America. Journal of AOAC International. v. 83, p.1167-1173, 2000.

CARINI, M.; FACINO, R. M.; ALDINI, G.; CALLONI, M.; COLOMBO, L. Characterization of phenolic antioxidants from maté (Ilex paraguariensis) by liquid chromatography/mass spectrometry and liquid chromatography/Tandem mass spectrometry. Rapid Communications in Mass Spectrometry. v.12, p.1813-1819, 1998. http://dx.doi.org/10.1002/(SICI)1097-0231(19981130)12:22<1813::AID-RCM379>3.0.CO;2-\#.

CLIFORD, M. N.; RAMIREZ-MARTINEZ, J. R. Chlorogenic acids and purine alkaloids contents on mate (Ilex paraguariensis) leaf and beverage. Food Chemistry. v.35, p.13-21, 1990. http://dx.doi.org/10.1016/03088146(90)90126-O

COSTA JÚNIOR, L. C. G.; PINHEIRO, A. J. R. Influência da relação caseína/gordura nas características físicoquímicas do queijo prato. Revista do Instituto de Laticínios Cândido Tostes. v. 305, p.29-49, 1998.

III Diretrizes Brasileiras Sobre Dislipidemias e Diretriz de Prevenção da Aterosclerose do Departamento de Aterosclerose da Sociedade Brasileira de Cardiologia. Arquivos Brasileiros de Cardiologia. v. 77, 2001.

FILIP, R.; LÓPEZ, P.; GIBERTI, G.; COUSSIO, J.; FERRARO, G. Phenolic compounds in seven south american Ilex species. Fitoterapia. v.72, p. 774 -778, 2001. http://dx.doi.org/10.1016/S0367-326X(01)00331-8.

FILIP, R.; LOTITO, S. B.; FERRARO, G.; FRAGA, C. G. Antioxidant activity of Ilex paraguariensis and related species. Nutrition Research. v.20, p.1437-1446, 2000. http://dx.doi.org/10.1016/S0271-5317(00)80024-X

FURTADO, M. M.; AMORIM, A. C. B. Os pioneiros laticinistas dinamarqueses e a história do queijo prato. Indústria Laticínios. v.4, p.18-22, 2000.

GIANINI, S. D. Aterosclerose e dislipidemias. São Paulo: BG Editora e Produções Culturais Ltda., 1998.

GORZALCZANY, S.; FILIP, R.; ALONSO, M. R.; MINO, J.; FERRARO, G. E.; ACEVEDO C. Choleretic effect and intestinal propulsion of "mate" (Ilex paraguariensis) and substitutes or adulterants. Journal of Ethnopharmacology. v.75, p.291-294, 2001. http://dx.doi.org/10.1016/S0378-8741(01)00179-9.

GUGLIUCCI, A.; MENINI, T. Three different pathways for human LDL oxidation are inhibited in vitro by water extracts of the medicinal herb Achyrocline satureoides. Life Sciences. v. 71, p.693-705, 2002.

GUYTON, A. C. Tratado de Fisiologia Médica. Rio de Janeiro: Guanabara Koogan S.A., 1972.

KONDYLI, E.; KATSIARI, M. C.; MASOURAS, T.; VOUTSINAS, L. P. Free fatty acids and volatile compounds of low-fat feta-type cheese made with a commercial adjunct culture. Food Chemestry. v. 79, p.199-205, 2002. http://dx.doi.org/10.1016/S0308-8146(02)00132-2.

KRAUSS, R. M. Lipids and Lipoproteins in Patients whit Type 2 Diabetes. Diabetes Care. v. 27, p.1496-1504, 2004. http://dx.doi.org/10.2337/diacare.27.6.1496.

MANNINEN, V.; ELO, M. O.; FRICK, M. H.; HAAPA, K.; HEINONEN, O. P.; HEINSALMI, P.; HELO, P.; HUTTUNEN, J. K.; KAITANJEMI, P.; KOSKINEN, P.; MAENPAA, H.; MALKONEN, M.; MANTTARI, M.; 
NOROLA, S.; PASTERNACK, A.; PIKKARAINEN, J.; ROMO, M.; SJOBLOM, T.; NIKKILA, E. A. Lipid alterations and decline in the incidence of coronary heart disease in the Helsinki Heart Study. The Journal of the American Medical Association. v.260, p.641-651, 1988. http://dx.doi.org/10.1001/jama.1988.03410050061031.

MAZZAFERA, P. Maté drinking: caffeine and phenolic acid intake. Food Chemistry. v. 60, p.67-71, 1997. http://dx.doi.org/10.1016/S0308-8146(96)00311-1.

MIRANDA, D. D.; ARÇARI, D. P.; JUNIOR PEDRAZZOLI, J.; CARVALHO, P.D.; CERRUTI, S. M.; BASTOS, D. H.; RIBEIRO, M. L. Protective effects of mate tea (Ilex paraguariensis) on $\mathrm{H}_{2} \mathrm{O}_{2}$-induced DNA damage and DNA repair in mice. Mutagenesis. v. 24, p.375-381, 2008. http://dx.doi.org/10.1093/mutage/gen011.

MITRUKA, B. M.; RAWNSLEY, H. M. Clinical biochemical and Hematological Reference Values in Normal Experimental Animals. New York: Masson Publishing, 1977.

MORAES, F. P.; COLLA, L. M. Alimentos funcionais e nutracêuticos: Definições, legislações e benefícios à saúde. Revista Eletrônica de Farmácia. v. 3, p.109-122, 2006.

NEWEMAN, D. J.; PRICE, C. P. Renal function and nitrogen metabolites. In: BURTIS, C. A.; ASHWOOD, E. R. Tietz Textsbook of Clinical Chemitry.1999. p. 1204-1270.

RIL, F. T.; LOCH, C. R.; VALDUGA, A. T.; MACEDO, S. M. D.; CICHOSKI, A. J. Perfil bioquímico de ratos alimentados com iogurte contendo extrato de erva-mate (Ilex paraguariensis St. Hill.). Brazilian Journal of Food Technology. v.14, p.332-337, 2011. http://dx.doi.org/10.4260/BJFT2011140400039.

RODRIGUES, H. S.; DINIZ, Y. S.; FAINE, L. A.; ALMEIDA, J. A.; FERNANDES, A. A. H.; NOVELLI, E. L. B. Suplementação nutricional com antioxidantes naturais: efeito da rutina na concentração de colesterol-HDL. Revista de Nutrição. v.16, p.315-320, 2003. http://dx.doi.org/10.1590/S1415-52732003000300009.

SIERVOGEL, R. M.; WISEMANDLE, W.; MAYNARD, L. M.; GUO, S. S.; ROCHE, A. F.; CHUMLEA, W. C.; TOWNE, B. Serial changes in body composition throughout adulthood and their relationship to changes in lipid an lipoprotein levels. Arteriosclerosis, Thrombosis and Vascular Biology. v.18, p.1759-1764, 1998.

SOUZA, P. H. M.; SOUZA NETO, M. H.; MAIA, G. A. Componentes funcionais nos alimentos. Boletim da Sociedade Brasileira de Ciência e Tecnologia de Alimentos. v. 37, p.127-135, 2003.

VALDUGA, A. T. Uso sustentado e processamento de Ilex paraguariensis St. Hill. (Erva Mate). São Carlos, 2002. 241 f. Tese (Doutorado em Ciências). Programa de Pós Graduação em Ecologia e Recursos Naturais - Universidade Federal de São Carlos.

WILLIAMS, P. T. High-density lipoprotein cholesterol and other risk factors for coronary heart disease in female runners. The New England Journal of Medicine. v. 334, p. 1298-1304, 1996. http://dx.doi.org/10.1056/NEJM199605163342004.

Submetido em 06 nov. 2013; Aceito para publicação em 07 abr. 2014. 